\section{Fire Can Reduce Thorn Damage by the Invasive Callery Pear Tree}

\author{
David R. Coyle ${ }^{1}$, Brayden M. Williams ${ }^{1}$, and Donald L. Hagan ${ }^{1}$
}

AdDITIONAL INDEX WORDs. bradford pear, forest, management, prescribed fire, Pyrus calleryana

Summary. Callery pear (Pyrus calleryana) is an invasive tree across much of the eastern United States that can form dense thickets, and tree branches and stems are often covered in sharp thorns. Landowners and land managers attempting to manage callery pear infestations are faced with the challenge of killing and/or removing the trees while also avoiding thorn damage to equipment, which can lead to wasted time and increased costs. We evaluated fire as management tool to reduce the likelihood of equipment damage from callery pear thorns. Branches were collected in the field from callery pear trees that were killed by herbicide, and also from untreated trees, and half the branches from each group were then burned with a propane garden torch to simulate a lowintensity prescribed fire. After treatment, all branches were returned either to an old field or forest floor for 1 year, after which thorn puncture strength was evaluated and compared with freshly cut thorns. Herbicide treatment and location did not affect thorn strength, but burning reduced the likelihood that thorns would puncture a tire. Fire increased tip width, which reduced thorn sharpness. Burning also reduced wood strength, and fungi proliferated on burned thorns after 1 year in the field or forest. Both factors likely contributed to decreasing thorn strength and probability of puncture. Our results show that using prescribed fire as a management tool can weaken callery pear thorns and dull their tips, reducing the chance of equipment damage and costs associated with clearing land of this invasive species. Leaving cut callery pear trees on the ground for 1 year increased fungal colonization, which may also reduce thorn damage. Prescribed fire can be part of an effective integrated management plan for this, and possibly other, thorny invasive flora.

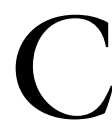
allery pear (Pyrus calleryana) was brought to the United States in the early 1900s for grafting onto fruit-producing european

$\overline{\text { Received for publication } 14 \text { May 2021. Accepted for }}$ publication 8 July 2021.

Published online 8 September 2021.

${ }^{1}$ Department of Forestry and Environmental Conservation, Clemson University, Clemson, SC 29634

We thank Clemson University Creative Inquiry Undergraduate Research program for providing funding to support this project and Webb Smathers for access to his property. Thoughtful comments from Nancy Loewenstein (Auburn University), Dan Tekiela (University of Wyoming), Sarah White (Clemson University), and four anonymous reviewers greatly improved this manuscript. We thank Marin Brewer (University of Georgia) for assistance identifying fungi.

This material is based on work supported by the U.S. Department of Agriculture (USDA), National Institute of Food and Agriculture under project no. SC-1700586. Any opinions, findings, conclusions, or recommendations expressed in this publication are those of the authors and do not necessarily reflect the view of the USDA.

Technical contribution no. 6999 of the Clemson University Experiment Station.

D.R.C. is the corresponding author. E-mail: dcoyle@clemson.edu.

This is an open access article distributed under the CC BY-NC-ND license (https://creativecommons. org/licenses/by-nc-nd/4.0/).

https://doi.org/10.21273/HORTTECH04892-21 pear (Pyrus communis) trees to aid in fire blight management efforts (Culley and Hardiman, 2007). Although this objective was largely accomplished, one particular callery pear individual was marketed as the bradford pear tree and was once commonly planted. It is now nearly ubiquitous in lawns and other managed landscapes across much of the eastern (and parts of the western) United States. Bradford pear trees are self-incompatible, but cross-pollination can occur with other pear (Pymus sp.) trees. This cross-pollination results in viable fruit that can be eaten by birds and other vertebrates, spread into new areas, and germinate (Culley, 2017; Culley and Hardiman, 2007).

Callery pear is now present across much of the eastern United States, growing in roadsides, old fields, vacant urban/suburban lots, and more recently encroaching into forested areas as shown in Fig. 1 (iNaturalist, 2021). Callery pear can grow in dense thickets and produce fruit in just a few years (Warrix et al., 2017), with seeds that can persist for more than a decade in the seedbank (Serota and Culley, 2019). Their growth form tends to be ramulose, and the many small branches are often covered in sharp thorn-like spur shoots (hereafter referred to as thorns), as shown in Fig. 2. Controlling callery pear requires sustained efforts, and several herbicides are effective (Flynn et al., 2015; Page et al., 2014; Vogt et al., 2020). However, lost in these control efforts is perhaps an equally urgent and practical question: what do land managers do about the thorns? Even after a callery pear tree has been killed with herbicide or cut down, the thorns remain sharp and dangerous. Many land managers and landowners have told the senior author (D.R.C.) about instances when callery pear thorns injured people and livestock, or punctured vehicle and wagon tires, as shown in Fig. 3. In some cases, hundreds to thousands of dollars and many work hours were lost because of equipment damage. How to avoid callery pear thorn damage is a common query from land managers and landowners involved with invasive species management.

Although prescribed fire is commonly used as a land management tool in the southern United States, fire alone is not a viable management option for callery pear (Warrix and Marshall, 2018). However, prescribed fire is being considered as part of a larger integrated pest management plan for callery pear, and knowing its effects on thorns may help land managers reduce damage to equipment and livestock. We hypothesized that fire would reduce the sharpness of thorns, while increasing their decomposition rate, thus resulting in a decreased probability of tire puncture.

\begin{tabular}{llll}
\hline $\begin{array}{l}\text { Units } \\
\text { To convert U.S. to SI, } \\
\text { multiply by }\end{array}$ & U.S. unit & SI unit & $\begin{array}{l}\text { To convert SI to U.S., } \\
\text { multiply by }\end{array}$ \\
\hline 0.3048 & $\mathrm{ft}$ & $\mathrm{m}$ & 3.2808 \\
2.54 & inch(es) & $\mathrm{cm}$ & 0.3937 \\
25.4 & inch(es) & $\mathrm{mm}$ & 0.0394 \\
6.8948 & $\mathrm{psi}$ & $\mathrm{kPa}$ & 0.1450 \\
$\left({ }^{\circ} \mathrm{F}-32\right) \div 1.8$ & ${ }^{\circ} \mathrm{F}$ & ${ }^{\circ} \mathrm{C}$ & $\left({ }^{\circ} \mathrm{C} \times 1.8\right)+32$
\end{tabular}




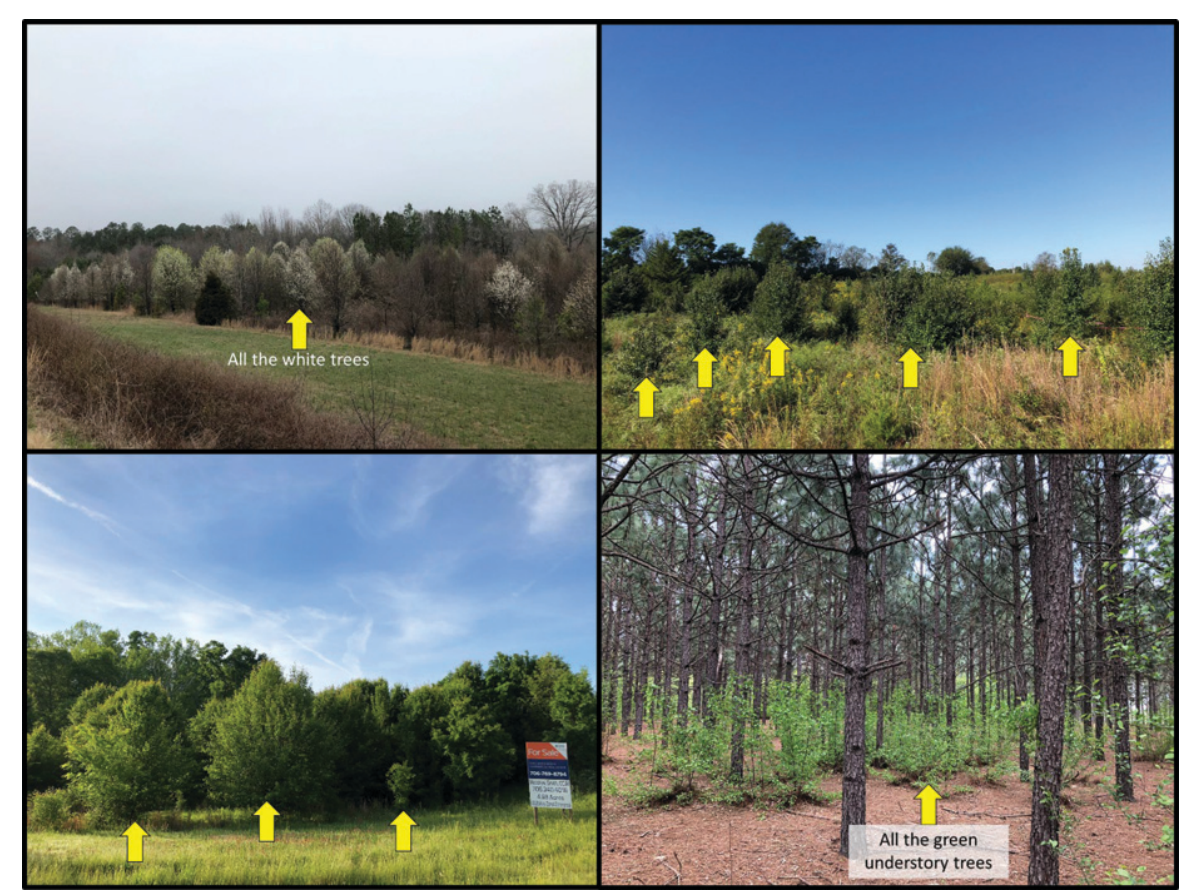

Fig. 1. Callery pear is common throughout various eastern U.S. landscapes and can be found along (A) roadsides, $(B)$ in old fields, $(C)$ in vacant lots, and (D) in mature forests. Yellow arrows point to individual or groups of callery pear (photos by D.R. Coyle).

\section{Materials and methods}

We conducted this study in an old field near Fair Play, SC (lat. 3432'58.5"N, long. 8258'43.7"W). This area has a humid subtropical climate, with hot summers and mild winters [Köppen-Geiger climate classification (Beck et al., 2018)]. The average annual temperature is $16.2^{\circ} \mathrm{C}$ and rainfall averages $1220 \mathrm{~mm} /$ year (Climatedata.org, 2021). Woody vegetation at this site was dominated by callery pear, with secondary components that included chickasaw plum (Prunus angustifolia), common persimmon (Diospyros virginiana), loblolly pine (Pinus taeda), and sweetgum (Liquidambar styraciflua). Groundcover vegetation consisted primarily of grasses [e.g., crowngrass (Paspalum sp.), bluestem grass (Andropogon sp.)]. Adjacent to the old field was a mixed pine-hardwood forest dominated by loblolly pine, sweetgum, and various oaks (Quercus $\mathrm{sp}$.). Groundcover in the forest site consisted of various forbs [e.g., horseweed (Conyza canadensis)], vines [e.g., carolina jessamine (Gelseminum sempervirens)], and sedges (Carex sp.).

Callery pear branch sections (each $\approx 12$ inches long) were collected from trees in Feb. 2019 or 2020 (Table 1$)$. Branches $(\mathrm{n}=200)$ came from standing dead trees (killed with herbicide in Fall 2018) or from untreated living trees $(\mathrm{n}=200)$. All trees were 2 to $3 \mathrm{~m}$ tall, and all branches were collected $\mathrm{l}$ to $2 \mathrm{~m}$ aboveground. Branches were generally 1 to 2 years old, and selection was based on thorn characteristics-specifically, uniform, stiff, and straight thorns around 2 to $4 \mathrm{~cm}$ long, as shown in Fig. 4. Thorns in this size range are strong and the most likely to result in a punctured tire. Branches from herbicide-treated trees $(\mathrm{n}=100)$

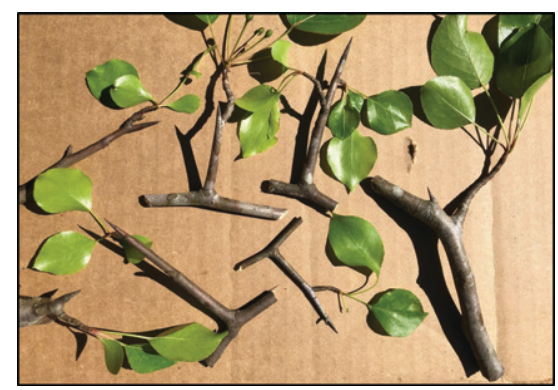

Fig. 2. Callery pear has a large diversity of thorn shapes and sizes, ranging from long and skinny to short and stout. Each thorn type poses unique dangers to people, animals, and equipment (photo by D.R. Coyle).

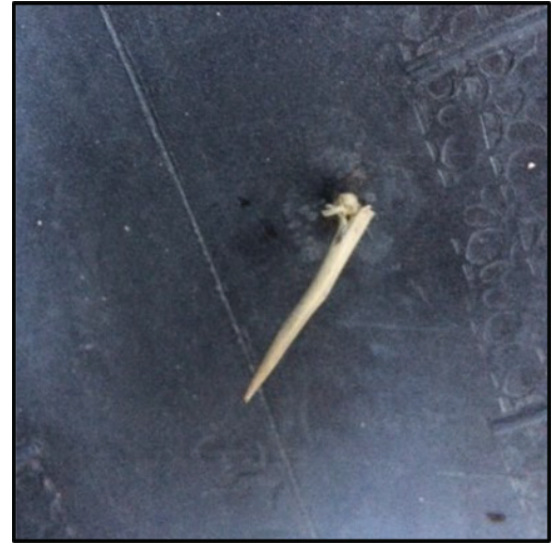

Fig. 3. Callery pear thorn that has punctured a tractor tire, shown from the inside of the tire (photo by $R$. Hodgson).

and untreated control trees $(\mathrm{n}=100)$ were then burned with a propane garden torch at its lowest setting for $15 \mathrm{~s}$ to simulate a low-intensity prescribed fire. This resulted in the branches being charred, but not consumed, as would be typical in a prescribed fire. Maximum fire temperature, measured with stainless steel type- $\mathrm{K}$ thermocouples (model TCP6-K12; Onset Computer Corp., Bourne, MA) was $270^{\circ} \mathrm{C}$, comparable to that of prescribed fires in the region (Coates et al., 2018).

Branches from each treatment were placed atop groundcover vegetation in the old field and mixed pine-hardwood forest and left for 1 year. We selected these two sites to assess how the presumed differences in abiotic and biotic conditions between them might influence decomposition rates, thorn sharpness, and probability of tire puncture. All branches were collected, labeled, and taken to the Clemson University Forest Ecology and Fire Science Laboratory, Clemson, SC, for testing in Feb. 2020, at which time 20 additional callery pear branches were collected from live trees in the old field. Ten of these

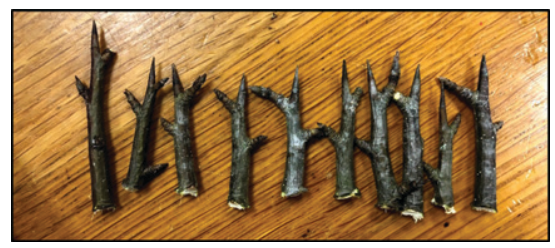

Fig. 4. Callery pear thorns used in the study were chosen based on size and shape (photo by B.M. Williams). 
Table 1. Ten treatments were used in the study to evaluate several potential management strategies for callery pear thorns. Treatments included a combination of herbicide-treated and untreated with herbicide overlayed with burned and unburned treatments; these evaluations were conducted on thorns that had sat on the ground for 1 year. Freshly cut, burned and unburned thorns were also evaluated.

\begin{tabular}{lcccl}
\hline Yr collected & Herbicide & Burned & Overwinter location & \multicolumn{1}{c}{ Field management strategy tested } \\
\hline 2019 & Yes & No & Field & Kill with herbicide, cut, leave on ground for l year \\
2019 & Yes & Yes & Field & Kill with herbicide, cut, burn, leave on ground for 1 year \\
2019 & No & No & Field & Cut, leave on ground for l year \\
2019 & No & Yes & Field & Cut, burn, leave on ground for 1 year \\
2019 & Yes & No & Forest & Kill with herbicide, cut, leave on ground for 1 year \\
2019 & Yes & Yes & Forest & Kill with herbicide, cut, burn, leave on ground for 1 year \\
2019 & No & No & Forest & Cut, leave on ground for l year \\
2019 & No & Yes & Forest & Cut, burn, leave on ground for 1 year \\
2020 & No & No & NA & No management \\
2020 & No & Yes & NA & Burn only \\
\hline
\end{tabular}

$\mathrm{NA}=$ not applicable.

branches were lightly burned with the propane torch to be used as fresh burned samples; 10 were unburned. Thus, 10 potential field management strategies were evaluated (Table 1).

Thorns (10 per treatment) that were uniformly straight and $36 \pm 0.6$ $\mathrm{mm}$ in length were then cut at the base from different branches. Thorn sharpness was determined by measuring the thorn's tip with a digital caliper to the nearest $0.01 \mathrm{~mm}$. Sharpness is important because thorns with wider tips are less sharp. Using a hydraulic press under consistent speed and pressure, thorns were then pressed between the treads of a strip of automotive tire. Tire thickness between treads was $\approx 5 \mathrm{~mm}$. We recorded whether the thorn punctured the tire or broke under the increasing pressure. Maximum puncture pressure (measured in kilopascals) was recorded for all successful punctures. Thorns that did not puncture were excluded from these measurements as a result of the difficulty of recording maximum puncture pressure accurately at the exact moment of thorn breakage. The tire strip was moved after each puncture attempt to ensure that each thorn contacted a different location on it. A three-factor analysis of variance was conducted to assess the how the different treatments (herbicide, fire, and location) and their interactions affect thorn sharpness and maximum puncture pressure. Probability of tire puncture, derived from a binary variable (yes/ no), was analyzed with a nominal logistic model. To tease out the effects of fire further, regardless of other treatments, subsequent $t$ tests (for sharpness and maximum puncture pressure) and $\chi^{2}$ tests (for probability of puncture) were performed to compare pooled burned vs. unburned treatments. Differences were considered significant at $\alpha=$ 0.05. All analyses were conducted using JMP (version 14; SAS Institute, Cary, NC).

\section{Results and discussion}

Neither herbicide treatment alone $\left(\chi^{2}=0.04, \mathrm{df}=1, P=0.78\right)$, location (field or forest, $\chi^{2}=0.08$, $\mathrm{df}=1, P=0.79)$, nor their interaction $\left(\chi^{2}=0.08, \mathrm{df}=1, P=0.82\right)$ impacted the probability that thorns would puncture a tire. Burning reduced the likelihood that a thorn would puncture a tire by impacting thorn sharpness and strength, as shown in Fig. 5.
Tip width (mean \pm SE) was significantly greater in burned $(1.17 \pm 0.08$ $\mathrm{mm})$ than unburned $(0.48 \pm 0.02$ $\mathrm{mm})$ treatments $(\mathrm{t}=8.5, \mathrm{df}=55, P<$ $0.01)$, and it took significantly greater pressure for burned $(165.5 \pm 9.7 \mathrm{kPa})$ than unburned $(113.8 \pm 4.1 \mathrm{kPa})$ thorns to puncture a tire $(\mathrm{t}=4.9$, $\mathrm{df}=45, P<0.01)$. There was a significantly greater chance that unburned thorns would puncture a tire $(92 \%$, $\mathrm{n}=46)$ compared with burned thorns $(70 \%, \mathrm{n}=35)\left(\chi^{2}=8.2, \mathrm{df}=1, P<\right.$ $0.01)$. Although fire can increase the hardness of sharp wooden points slightly, it also reduces wood strength and makes it more brittle (Ennos and Chan, 2016). Furthermore, fire can degrade the chemistry and structure of wood [see reviews by Bartlett et al.,

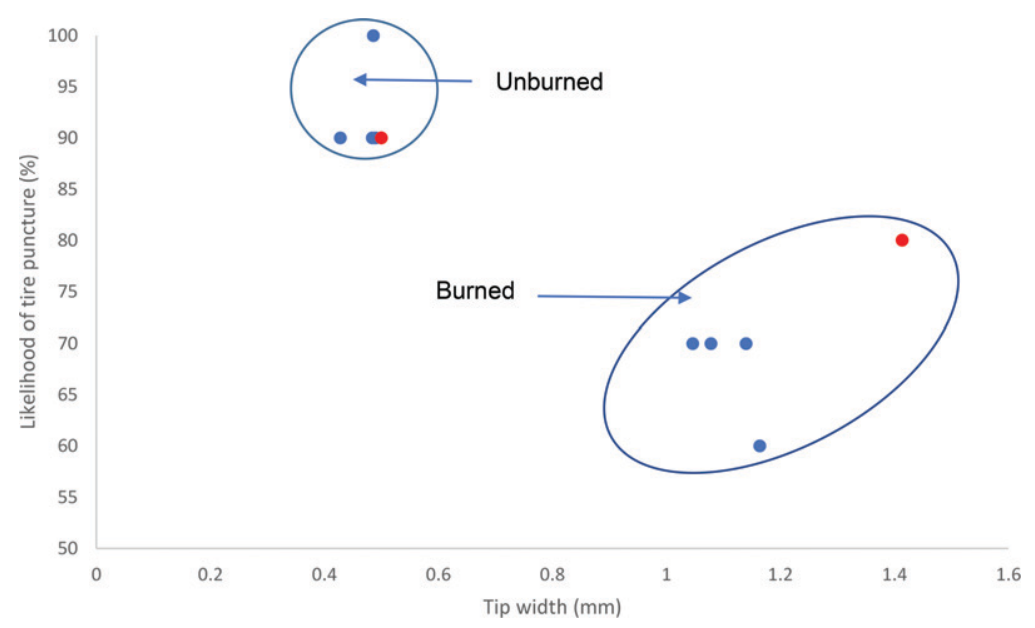

Fig. 5. Relationship between callery pear thorn tip width ( $x$-axis) and likelihood of tire puncture ( $y$-axis) for burned vs. unburned thorns. Red points, fresh samples; blue points, after 1 year of decomposition. Points represent the means of 10 thorns from each of the 10 management strategies outlined in Table 1. Statistical comparisons were conducted between burned and unburned treatment clusters (blue ovals) and declared statistically significant at $\alpha=0.05 ; 1 \mathrm{~mm}=$ 0.0394 inch. 
(2019) and Watson and Potter (2004)], and, as predicted, did reduce the chance of a tire puncture.

Although these data support the idea that prescribed fires-which are commonly used land management techniques, especially throughout much of the eastern United Statescan benefit landowners and land managers by reducing the likelihood of tire punctures from callery pear, they also highlight the resilience of callery pear thorns. Even after 1 year of decomposition and a fire, there was still a puncture rate of $70 \%$ in our study, although this was based on presumably unlimited pressure. We were unable to test this using actual vehicles to determine whether typical vehicles used in these areas were heavy enough to result in tire puncture, although this is a logical next step. A hotter fire, or a fire that burned for a longer duration, would likely further decrease the probability of puncture by reducing wood strength (Bartlett et al., 2019). Many factors influence fire behavior, and in a field setting these would include ignition technique (head fire, or a fire that advances with the wind; backing fire, or a fire that advances into the wind; or flanking fire, a fire that travels parallel to the wind), wind speed, humidity, fuel moisture, and ambient temperature (Waldrop and Goodrick, 2018). Managers have some ability to manipulate fire outcomes by burning under the conditions that produce the desired fire behavior.

Burned branches left in the field for 1 year had rates of puncture that were not statistically different from freshly cut branches $(P=0.20)$. However, we noticed anecdotally several instances when, after 1 year of decomposition in the field, burned thorns were being colonized by various species of fungi, as shown in Fig. 6. Fungi were largely absent on unburned thorns. White rot fungi, which preferentially degrade wood from hardwood trees, consume lignin (Daniel, 2016) - a component of wood that gives it strength-and to that end, fungal decay is known to reduce wood strength in several hardwood tree species (Blanchette, 1984, 1991; Eslyn and Highley, 1976). Therefore, allowing callery pear to sit for 1 year (or more) in the field could also help decrease the likelihood of a

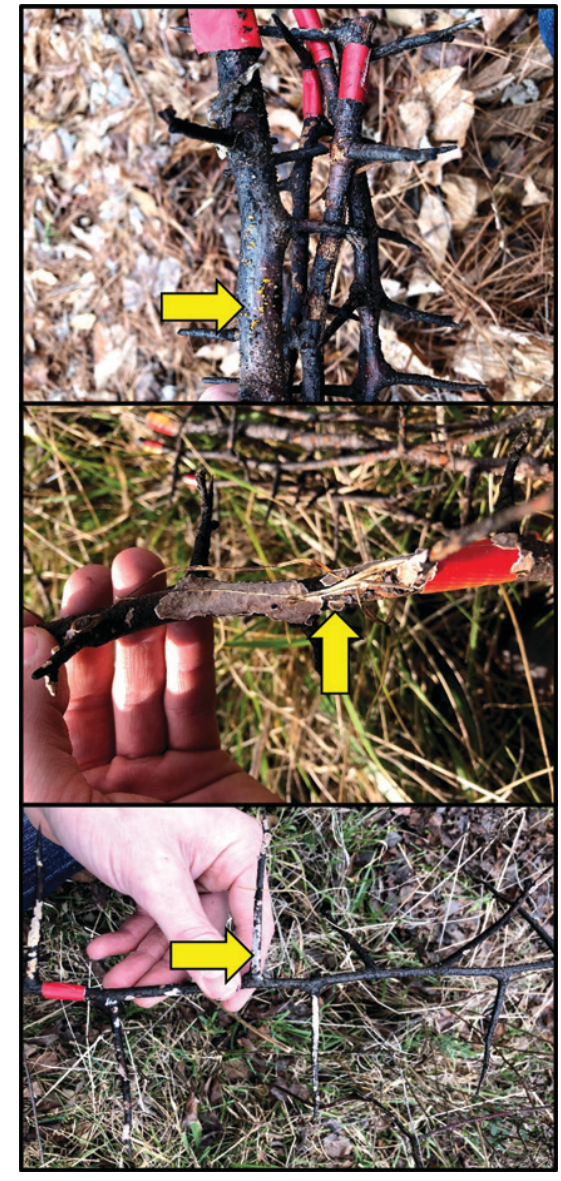

Fig. 6. Several different types of basidiomycete fungi were found growing on callery pear branches that had been cut and sat for 1 year in the field. This was especially prevalent on burned branches (photos by B.M. Williams).

tire puncture resulting from fungal decomposition, reducing thorn strength, especially when fire is also used.

Although many different types of thorns can be found on a single callery pear tree and all of them can injure living things, some are likely structurally too weak or too short to puncture a tire. Our study measured the impact of fire on what we believed were the most likely thorns to puncture a tire-those long and strong enough to reach between tire treads. Our study only showed a modest overall decrease in puncture risk resulting from burning, but landowners and land managers agree that any technique that reduces potential damage would be worthwhile (D.R. Coyle, personal communication with landowners and land managers).
Using prescribed fire as a management tool helped reduce the likelihood of damage from thorns, and this tactic may also be useful for other thorny, woody invasive species. In the United States, shrubby olive (Elaeagnus sp.), buckthorn (Rhamnus sp.), trifoliate orange (Poncirus trifoliata), and nonnative roses (Rosa sp.) all have thorns on their branches that can injure people or damage equipment. Black locust (Robinia psendoacacia), which has sharp, thornlike stipular spines, is an invasive species in Europe and, although native to the United States, is often managed as an invasive species because of its propensity for taking over pastures and other areas. As with callery pear, fire may top-kill these species, but prolific resprouting is likely to occur (Anderson and Brown, 1980). However, prescribed fire does have potential as a component of an integrated management plan for callery pear.

\section{Conclusion}

Callery pear continues to spread and impacts many landowners in the United States, and landowners and land managers incur considerable costs to eliminate this tree. Metaltracked equipment can eliminate the possibility of tire puncture, but these machines are not always available or affordable. Prescribed fire can help reduce damage from this plant pest, especially in forested or old-field scenarios. Ultimately, an integrated pest management plan is required to manage this pest effectively, because a single tactic or treatment rarely eliminates it permanently in heavily infested areas.

\section{Literature cited}

Anderson, R.C. and L.E. Brown. 1980. Influence of prescribed fire on colonizing black locust, p. 330-336. In: H.E. Garrett and G.S. Cox (eds.). Proc. Central Hardwood For. Conf. III., University of Missouri, Columbia.

Bartlett, A.I., R.M. Hadden, and L.A. Bisby. 2019. A review of factors affecting the burning behaviour of wood for application to tall timber construction. Fire Technol. 55:1-49, doi: 10.1007/s10694018-0787-y.

Beck, H.E., N.E. Zimmermann, T.R. McVicar, N. Vergopolan, A. Berg, and E.F. Wood. 2018. Present and future KöppenGeiger climate classification maps at $1-\mathrm{km}$ 
resolution. Sci. Data 5:180214, doi: 10.1038/sdata.2018.214.

Blanchette, R.A. 1984. Screening wood decayed by white rot fungi for preferential lignin degradation. Appl. Environ. Microbiol. 48:647-653, doi: 10.1128/aem.48. 3.647-653.1984.

Blanchette, R.A. 1991. Delignification by wood-decay fungi. Annu. Rev. Phytopathol. 29:381-398, doi: 10.1146/annurev. py.29.090191.002121.

Climatedata.org. 2021. Clemson climate (United States of America). 7 July 2021. <https://en.climate-data.org/northamerica/united-states-of-america/ south-carolina/clemson-8968/>.

Coates, T.A., A.T. Chow, D.L. Hagan, T.A. Waldrop, G.G. Wang, W.C. Bridges, Jr., M.-F. Rogers, and J.H. Dozier. 2018. Thermocouple probe orientation affects prescribed fire behavior estimation. J. Environ. Qual. 47:170-176, doi: 10.2134/jeq2017.02.0055.

Culley, T.M. 2017. The rise and fall of the ornamental callery pear tree. Amoldia 74:1-11.

Culley, T.M. and N.A. Hardiman. 2007. The beginning of a new invasive plant: A history of the ornamental callery pear tree in the United States. Bioscience 57:956-964, doi: 10.1641/B571108.

Daniel, G. 2016. Fungal degradation of wood cell walls, p. 131-167. In: Y.S.
Kim, R. Funada, and A.P. Singh (eds.). Secondary xylem biology: Origins, functions, and applications. Academic Press/ Elsevier, New York, NY.

Ennos, A.R. and T.L. Chan. 2016. 'Fire hardening' spear wood does slightly harden it, but makes it much weaker and more brittle. Biol. Lett. 12:20160174, doi: 10.1098/ rsbl.2016.0174.

Eslyn, W.E. and T.L. Highley. 1976. Decay resistance and susceptibility of sapwood of fifteen tree species. Phytopathology 66:1010-1017, doi: 10.1094/Phyto66-1010.

Flynn, S., R.J. Smeda, and C. Page. 2015. Control of callery pear in pastures, rights-of-ways, and natural areas, p. 219. In: Proc. 70th Annu. Mtg. North Central Weed Sci. Soc., 7-10 Dec. 2015. Indianapolis, IN.

iNaturalist. 2021. Map of Pyrus calleryana research grade observations. 21 Mar. 2021. <https://www.inaturalist.org/ observations?place_id=any\&quality_grade =research $\|$ subview=map\&taxon_id=1197 93\&verifiable $=$ any $>$.

Page, C., E.S. Flynn, and R. Smeda. 2014. Management of callery pear (Pyrus calleryana) on urban roadsides, p. 35-36. In: Proc. 69th Annu. Mtg. North Central Weed Sci. Soc., 1-4 Dec. 2014. Minneapolis, MN.
Serota, T. and T.M. Culley. 2019. Seed germination and seedling survival of invasive callery pear (Pyrus calleryana Decene.) 11 years after fruit collection. Castanea 84:47-52.

Vogt, J.T., D.R. Coyle, D. Jenkins, C. Barnes, C. Crowe, S.G. Horn, C. Bates, and F.A. Roesch. 2020. Efficacy of five herbicide applications for control of Pyrus calleryana. Invasive Plant Sci. Mgt. 13:252-257, doi: 10.1017/inp. 2020.36 .

Waldrop, T.A. and S.L. Goodrick. 2018. Introduction to prescribed fires in Southern ecosystems. Science update SRS-054. U.S. Department of Agriculture Forest Service Southern Research Station, Asheville, NC.

Warrix, A.R. and J.M. Marshall. 2018. Callery pear (Pyrus calleryana) response to fire in a managed prairie ecosystem. Invasive Plant Sci. Mgt. 11:27-32, doi: 10.1017/inp.2018.4.

Warrix, A.R., A.L. Myers, and J.M. Marshall. 2017. Estimating invading callery pear (Pyrus calleryana) age and flowering probability in an Indiana managed prairie. Proc. Indiana Acad. Sci. 126:153-157.

Watson, P. and S. Potter. 2004. Burned wood in the pulp and paper industry: A literature review. For. Chron. 80: $473-477$. 